cord during ischemia. Ann Thorac Surg 1986;41: 551-6.

2. Hall ED, Yonkers PA, Andrus PK, Cox JW, Anderson DK. Biochemistry and pharmacology of lipid antioxidants in acute brain and spinal cord injury. $\mathrm{J}$ Neurotrauma 1992;9(Suppl 2):S425-42.

3. Reddy BR, Kloner RA, Przylenk K. Early treatment with deferoxamine limits myocardial ischemic/reperfusion injury. Free Radic Biol Med 1989;7:45-52.
4. Kontoghiorghes GJ, Jackson MJ, Lunec J. In vitro screening of iron chelators using models of free radical damage. Free Radic Res Commun 1986;2:11524.

5. Reuter DG, Tacker WA, Badylak SF, Voorhees WD III, Konrad PE. Correlation of motor-evoked potential response to ischemic spinal cord damage. J THORaC Cardiovasc Surg 1992;104:262-72.

\title{
RELIEF OF COMPLEX LEFT VENTRICULAR OUTFLOW TRACT OBSTRUCTION WITH PULMONARY AUTOGRAFTS
}

\author{
Ulrik Hvass, MD, Didier Chatel, MD, José Calliani, MD, and Yves Pansard, MD, Paris, France
}

Pulmonary autografts harvested with a larger than usual amount of anterior ventricular infundibulum $(2$ to $3 \mathrm{~cm}$ instead of approximately $1 \mathrm{~cm}$ ) may be used for complete relief of complex left ventricular outflow tract obstructions. The autograft obtained renders prosthetic septal reconstruction unnecessary, as has been reported by Daenen and Gewillig. ${ }^{1}$

We used this technique in two patients, 5 and 6 years of age, who had a diminutive aortic anulus and diffuse subaortic obstructions. One patient had had a transaortic resection 3 years earlier.

The general lines of the operation are those of aortic root replacement with pulmonary autografts. ${ }^{2}$ The pulmonary artery is transected at the bifurcation, and then the pulmonary ventricular infundibulum is incised transversely about $3 \mathrm{~cm}$ from the pulmonary valve anulus. Excision of the pulmonary root is completed, reducing this distance laterally to the usual 4 to $6 \mathrm{~mm}$. Exposure and enlargement of the interventricular septum is much more comfortable than in the Konno operation. ${ }^{3}$ Starting at the intercoronary commissure, the septal incision is continued into the infundibular septum. Because the pulmonary autograft is already larger than the diminutive aortic anulus, the septal opening may be extended 3 to $4 \mathrm{~cm}$, allowing for an efficient enlargement of the left ventricular outflow tract. The septum is augmented with the autograft's larger than usual anterior muscular flap, similar to the

From Hopital Bichat, Chirurgie Cardio Vasculaire, Paris, France. J THORAC CARDIOVASC SURG 1995;109:1019

Copyright $(1) 1995$ by Mosby-Year Book, Inc. $0022-5223 / 95 \$ 3.00+0 \quad \mathbf{1 2 / 8 / 6 1 2 8 1}$ technique reported for aortoventriculoplasties with aortic allografts retaining the anterior mitral leaflet. ${ }^{4}$

Postoperative echocardiograms (follow-up of 6 and 2 months) with Doppler recordings show efficient relief of obstruction with low residuel gradients and less than trivial central regurgitation.

The technique has two advantages: First, no prosthetic material is used; a Dacron patch in contact with the autograft exposes leaflets to abrasion. ${ }^{5}$ Second, the technique is relatively simple to do.

\section{REFERENCES}

1. Daenen W, Gewillig M. Extended aortic root replacement with pulmonary autografts. Eur J Cardiothorac Surg 1993;7:42-6.

2. Matsuki O, Okita Y, Almeida RS, et al. Two decades of experience with aortic valve replacement with pulmonary autograft. J Thorac Cardiovasc Surg 1988;95: 705-11.

3. Konno S, Imai Y, Lida Y, Nakajima M, Tatsuno K. A new method for prosthetic valve replacement in congenital aortic stenosis associated with hypoplasia of the aortic valve ring. J THORAC CARDIOvasC SuRG 1975;70: 909-17.

4. McKowen RL, Campbell DN, Woelfiel GF, Wiggins JW, Clarke DR. Extended aortic root replacement with aortic allografts. J Thorac CARDIovasc SuRg 1987;93: 366-74.

5. Elkins RC, Knott-Craig CJ, Ward KE, McCue C, Lane MM. Pulmonary autograft in children: realized growth potential. Ann Thorac Surg 1994;57:1387-94. 